NASA Technical Memorandum 88787

\title{
Fiber Composite Sandwich Thermostructural Behavior: Computational Simulation
}

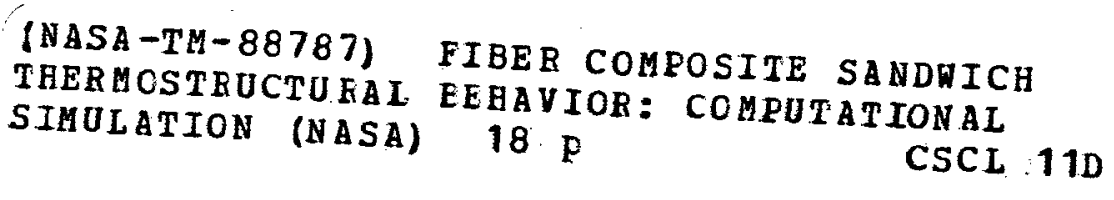

N86-316.63

G3/24 Unclas $43490=$

C.C. Chamis and R.A. Aiello

Lewis Research Center

Cleveland, Ohio

and

P.L.N. Murthy

Cleveland State University

Cleveland, Ohio

Prepared for the

27th Structures, Structural Dynamics, and Materials Conference (SDM) cosponsored by the AIAA, ASME, ASCE, and AHS

San Antonio, Texas, May 19-21, 1986 


\section{F IBER COMPOSITE SANDWICH THERMOSTRUCTURAL BEHAVIOR: COMPUTATIONAL SIMULATION \\ C.C. Chamis* and R.A. Alellot \\ National Aeronautics and Space Administration \\ Lewis Research Center \\ Cleveland, Ohio 44135 \\ and \\ P.L.N. Murthytt \\ Cleveland State University \\ Civil Engineering Department \\ Cleveland, Ohio 44115}

\section{SUMMARY}

Several computational levels of progressive sophistication/simplification are described to computationally. simulate composite sandwich hygral, thermal, and structural behavior.

The several computational levels of sophistication include: (1) threedimensional detailed finite element modeling of the honeycomb, the adhesive and the composite faces: (2) three-dimensional finite element modeling of the honeycomb assumed to be an equivalent continuous, homogeneous medium, the adhesive and the composite faces; (3) laminate theory simulation where the honeycomb (metal or composite) is assumed to consist of plies with equivalent properties; and. (4) derivations of approximate, simplified equations for ther: mal and mechanical properties by simulating the honeycomb as an equivalent homogeneous medium. The approximate equations are combined with composite hygrothermomechanical and laminate theories to provide a simple and effective computational procedure for simulating the thermomechanical/thermostructural behavior of fiber composite sandwich structures.

\section{INTRODUCTION}

The use of fiber composites in space applications is increasing in a variety of structural configurations. Sandwich structural configurations provide an effective application of fiber composites. The faces of the sandwich resist loads by membrane action which is one of the most structurally-efficient use of fiber composite thin laminates. In addition, composite sandwich structures can be designed to meet very close thermal distortion tolerances such as those required for communication satelitite antennas and reflectors.

* Senior Research Engineer.

tAerospace Structures Eng.ineer.

t+ Senior Research Associa.te in Computational Mechanics. 
Designs to meet close thermal distortion tolerances are developed by detalled thermal and structural analyses. These analyses require thermal and mechanical properties of the composite sandwich as well as temperature and moisture effects on these properties. The thermal properties required include heat capacity and thermal conductivities and thermal expansion coefficients in the plane and through the thickness of the sandwich. The corresponding mechanical properties include normal and shear moduli, and Poisson's ratios. Thermomechanical and corresponding thermostructural properties of sandwich components can, in principle, be measured experimentally. This is practical only for one or at most a few sandwich configurations, limited temperature/moisture conditions and generally for selected properties.

The alternative is to computationally simulate the thermomechanical behavior of composite sandwich structures so that all the properties required for thermal and mechanical/structural analyses can be predicted. Recent analytical studies at Lewis Research Center focused on developing computational methods for simulating the thermomechanical behavior of composite sandwich structures. These methods use analyses with several levels of progressive sophistication/simplification in conjunction with composite hygrothermomechanical theory. The objective of this paper is to describe these computational simulation methods and summarize results obtained therefrom.

The several computational levels of sophistication include: (1) threedimensional finite element modeling of the honeycomb, the adhesive and the composite faces; (2) three-dimensional finite element modeling of the honeycomb assuming an equivalent homogeneous medium, the adhesive and the composite faces; (3) laminate theory simulation where the honeycomb (metal or composite) is assumed to be of plies with equivalent properties; and (4) approximate, simplified equations for simulating the honeycomb thermal and mechanical properties with an equivalent homogeneous medium. These levels of sophistication/ simplification have been packaged into a procedure which is embedded in a composite mechanics computer code (ref. 1) streamlined for the computational simulation of composite sandwich hygral, thermal, and structural behavior. The steps for developing such a procedure and its subsequent embedment. in a computer code are described in outline form.

\section{THREE-DIMENSIONAL DETAILED FINITE ELEMENT MODEL}

The three-dimensional detailed finite element simulation includes simulation of the (1) core, (2) adhesive, and (3) faces. The core is simulated using three plate elements through the core thickness in order to determine equivalent mechanical and thermal properties and possible core buckling. The finite element model of a core generated by MSC/NASTRAN is shown in figure 1. The core for this model is $0.375 \mathrm{in}$. high. The model consisted of 380 nodes, 375 elements, and $2280^{\circ}$ of freedom (DOF). The model was used to determine nine equivalent mechanical properties ( $E_{\text {exx }}, E_{\text {eyy }}, E_{e z z}, G_{e x y}, G_{e y z}, G_{e z x}, v_{e x y}$ $v_{e y z}, v_{e z x}$ ) and six equivalent thermal properties ( $\alpha_{e x x}, \alpha_{e y y}, \alpha_{e z z}$, Kexx. $\left.K_{e y y}, K_{e z z}\right)$. The notation is as follows: E denotes normal (Young's) modulus, $G$ denotes shear modulus, $v$ denotes Poisson's ratio, a denotes thermal expansion coefficient, and $K$ denotes thermal heat conductivity. The subscript $e$ denotes core equivalent property while the subscripts $x, y$, and $z$ denote core coordinate reference plane (first) and direction (second). The material properties used with the finite element model are summarized in table I. 
The equivalent mechanical properties of the core are determined by loading the model with imposed displacements in each direction at one end (or face) while fixing the opposite end (or face). The desired property is determined by using corresponding mechanics of materials equations. For example, Eezz $=N_{c x x} l_{x} / A_{x} u$ where $N_{c x x}$ is the reaction force due to imposed displacement $u$ at $x=1 x, l_{x}$ is the length of the core in the $x$ direction, $A_{x}$. is the core projected area on a plane with normal along the $x$ direction and $u$ is the imposed displacement. The Poisson's ratio ${ }^{v_{c x y}}=2 v 7_{x} / u l_{y}$ where $v$ is the average of all nodal displacements at the $y=0$ and $y=9_{y}$ faces and $u$ is the imposed displacement. The remaining mechanical properties are determined in a similar manner. The thermal properties are also determined in a similar manner, except that the imposed displacements are replaced with appropriate thermal conditions.

Deformed finite element plots superimposed over the undeformed models are shown in figures 2 to 7 for the nine different mechanical properties. These figures are included to show that the honeycomb wall did not undergo large deformations in any of the different loading conditions so that no linear solution is required. Displacements were imposed in two planes, for example, $x y$ and $y x$ (figs. 5 to 7 ) in order to determine the equivalent shear moduli and their respective symmetries. The equivalent mechanical properties of the core determined from these cases are summarized in table II for two cell sizes (1/4 and $1 / 8$ in.). As can be seen: (1) the normal moduli are small because the noneycomb deforms like an accordion in these directions, and (2) some shear moduli are unequal and Poisson's ratios do not satisfy the well known reciprocity rules. That is, the $y$ property is not equal to the $x$ property, for example. This implies that the behavior of the core is load-direction dependent when the mechanical properties are determined from the simple, basic mechanics of materials definitions. It is important, therefore, in measuring and reporting these properties to include the specific plane and direction in order to use them properly in simulated core or structural sandwich analysis. The unequal shear moduli and Poisson's ratios demonstrate that the honeycomb core behaves like an equivalent homogeneous anisotropic solid.

The computational simulation of the entire sandwich is parallel to that of the fabrication procedure. First the core is simulated as already described. Second the adhesive layers are simulated with a single layer of solid finite elements on both sides of the core. Third, the composite faces are simulated with a single layer of solid elements over the adhesive on each side. An xploded schematic of the MSC/NASTRAN finite element model is shown in figure 8 .

This model consists of 760 nodes, 711 elements, and 2850 DOF. The material properties used are those in table $I$.

The equivalent properties of the sandwich are determined by loading the model with imposed displacements as was done for the core. Typical results obtained are summarized in table III under detalled model. It can be seen from these results and referring to table I that the in-plane properties of the sandwich are mainly controlled by the faces while the flat-wise (throughthe-thickness) properties are controlled by the core.

\section{THREE-DIMENSIONAL FINITE ELEMENT MODEL WITH EQUIVALENT CORE}

This approach is the first step in the progressive simplification for simulating the composite honeycomb sandwich using laminate theory. The finite 
element model for this simulation consisted of four layers of solid elements for the core, one single layer of solid elements for the adhesive on each side of the core, and two layers of solid elements for each face. A computer schematic of the finite element model used for determining the structural properties is shown in figure 9. The model consists of 2475 nodes, 1960 elements, and 7425 DOF: The material properties for the model were those in table I for the adhesive and the faces. Those for the honeycomb core were the equivalent properties determined from the three-dimensional detailed finite element model listed in table II. The properties of the grouping of plies represented by the solid elements for the faces were determined using a composite mechanics code ICAN (ref. 1). Each grouping consisted of two $(+60$, $-60,0)$ layers to simulate the six ply $\left[ \pm 60,0_{2},+60\right]$ face sheet in order to have a minimum thickness laminate with in-plane isotropic behavior for mechanical and thermal properties. A 40-in.-square sandwich with the same thickness and same modeling detall was used for determining the thermal expansion coefficients in order to obtain uniform thermal expansion in all planes. This finite element model was loaded to determine the sandwich structural and thermal properties as was done for both the honeycomb core and the three-dimensional detailed finite element model. Results obtained from this simulation are described later in the results and comparison section.

\section{LAMINATE THEORY}

Laminate theory is the second level in the progressive simplification for simulating structural sandwich behavior. In the studies summarized herein the sandwich was simulated using laminate theory as follows: (1) four plies for the core, (2) one ply for each of the adhesive layers, and (3) six plies for each of the faces. The desired structural and thermal properties are directly determined from the analysis and are routine output properties from the ICAN code.

The input properties for this simulation are those used for composite micromechanics and most of them are avallable in the ICAN resident data bank. The equivalent properties for the honeycomb were modeled using assumed fiber/ matrix properties to match those determined from the core three-dimensional detalled finite element model. It is important to note that in this simulation the number of plies used for the faces is equal to that in the actual sandwich. The number of plies for the adhesive and the core is the choice of the user. These can be selected to account for nonuniform temperature and moisture profiles. The hygrothermal effects on the sandwich structural and thermal properties can readily be predicted using laminate theory which accounts for these effects. Properties obtained from this simulation using ICAN are summarized in the next section.

\section{RESULTS, COMPARISONS AND DISCUSSION}

The results obtained from the three different simulation methods are summarized in table III. As can be seen the results from all three simulation methods are generally in close agreement except for some Poisson's ratios as explained later. Considering the three-dimensional detailed finite element model as being the most accurate, it can be seen that laminate theory can reasonably accurately predict the structural and thermal properties of sandwich structures. This is a significant finding since composite mechanics computer 
codes can be used to simulate structural and thermal sandwich behavior and conduct parametric studies, including hygrothermal effects, in a near-routine and very. cost-effective manner. Typical thermal expansion coefficient results obtained in this manner (using ICAN) are plotted in figures 10 and 11 for composite sandwiches with different laminate configurations and with different honeycomb material suitable for applications to communication satellites. The near-zero in plane thermal expansion coefficients as well as the hygrothermal effects on these coefficients are illustrated. The apparent discrepancies are mainly due to the effects of the free edges in the relatively small size model for the three-dimensional detail finite element. These same effects also influence the $\alpha_{Z z}$ thermal expansion coefficient. The model-size free-edge effects were evaluated using the three-dimensional finite element model with homogeneous core. A finite element model size of 40 by 40 in. was necessary to practically eliminate the free-edge effects.

\section{APPROXIMATE EQUATIONS FOR EQUIVALENT CORE PROPERTIES}

A set of simple equations are presented for predicting homogeneous-core equivalent honeycomb properties. These equations are the third approach to the progressive simplification of composite sandwich panels. The equations can be used to predict approximate properties for a honeycomb core made from any material, for example, metal, nomex, or composite. The equations are derived with the aid of figure 12. Note the figure reference coordinate axes and the schematics showing the stresses in the honeycomb core wall. The subscripts used in the notation for the core properties refer to this figure. The equations were derived assuming that the honeycomb walls resist/react stress through membrane (inplane) action only. The rationale for assuming only inplane action is that the sandwich faces will prevent excessive bending and/or. linkage-type behavior of the honeycomb walls.

The resulting equations are summarized in table IV together with their respective predictions. Included are also predictions from finite element simulations for (1) a single cell with faces to prevent core wall bending and without faces, and (2) the three-dimensional detalled finite element model for the core only. The coefficients in the approximate equations were siightiy adjusted from those derived for the mechanistic models so that predictions correlate with the finite element simulations. It is worth noting that the approximate equations depend only on core wall thickness ( $t$ ), cell size (w) and core wall material properties. It is also worth noting that core properties $E_{\text {exx }}$ and $E_{\text {eyy }}$ are practically "zero" and vexy is approximately unity for the core when it is not restrained. The stress-strain states used to determine these unrestrained core properties require the core to respond as an integrated linkage system because of the large bending displacements of the core wall which are very thin $(0.0007 \mathrm{in.})$.

A procedure was developed to use these approximate equations in conjunction with composite mechanics in order to simulate sandwich thermal/structural behavior. The steps of this procedure are as follows: (1) obtain the core material properties from suppliers, (2) use the approximate equations to determine equivalent homogeneous core properties, (3) select fiber/matrix properties with the aid of composite micromechanics equations (ref. 2) to reproduce the core equivalent properties, (4) use the micromechanics equations to predict all ply properties needed for laminate analysis, (5) select the 
number of plies to represent the adhesive and the core, and ( 6 ) use laminate theory (refs. 3 to 5) to predict the desired properties.

The procedure just outlined is embedded in the ICAN computer code. In addition, ICAN was appropriately modified and packaged as a stand-alone port-: able code for the computational simulation of structural sandwich hygrothermomechanical behavior. The resulting code is identified as ICAN/SCS for Integrated Composite Analyzer for Structural-Sandwich Computational Simulation. ICAN/SCS output includes material cards for solid and plate finite element structural analysis as well as ply and interply stress analysis. The ply and interply stress analysis of the core has to be carefully interpreted since the honeycomb is replaced with an equivalent homogeneous, continuous anisotropic solid.

\section{SUMMARY}

The thermal and structural behavior of composite sandwich panels with a honeycomb core has been computationally simulated using several computational levels of progressive sophistication/simplification. These levels include: (1) three-dimensional detailed finite element modeling, (2) three-dimensional finite element modeling assuming a homogeneous core, (3) laminate theory, and (4) simple equations for predicting the equivalent properties of the honeycomb core. A procedure was developed and embedded in a composite mechanics computer code which can be used to conduct parametric studies in order to determine "optimum" composite sandwich configurations for specific applications. The procedure developed makes it possible and computationally. effective to evaluate composite sandwich behavior at the global, local, laminate, ply, and micromechanics levels when the composite sandwich is subjected to hygral, thermal, and mechanical loading environments. The cross correlation at the various computational levels of progressive simplification provide credence that the sandwich behavior so simulated is representative and consistent with the assumed physics.

\section{REFERENCES}

1. Murthy, P.L.N.; and Chamis, C.C.: ICAN: Integrated Composite Analyzer. AIAA Paper 84-0974, May 1984.

2. Chamis, C.C.: Simplified Composites Micromechanics Equations for Hygral, Thermal, and Mechanical Properties. SAMPE, Q., vol. 15, no. 3, Apr. 1984, pp. 14-23.

3. Chamis, C.C.: Prediction of Fiber Composite Mechanical Behavior Made. Simple. Rising to the Challenge, SPI 35th Annual Conference, Soclety of the Plastics Industry, 1980, Session 12-A, pp. 1-1.0.

4. Chamis, C.C.: Prediction of Composite Thermal Behavior Made Simple. Working Together for Strength, SPI 36 th Annual Conference, Society of the Plastics Industry, 1981, Session 12-B, pp. 1-11.

5. Chamis, C.C.; and Sinclair, J.H.: Prediction of Composites Hygral Behavior Made Simple. Leading From Strength, SPI 37 th Annual Conference, Washington, Society of the plastics Industry, 1982, Session 24-E, pp. 1-9. 
TABLE I. - PROPERTIES USED AS INPUT TO THE SIMULATION MODELS

\begin{tabular}{|c|c|c|c|c|c|c|c|}
\hline Property & Units & Symbol & Direct. & $\begin{array}{l}\text { Aluminum } \\
\text { core }\end{array}$ & $\begin{array}{c}\text { Unidirection } \\
\text { composite } \\
(\mathrm{Ply}) \\
(T-300 / \text { IMHS })\end{array}$ & $\begin{array}{l}\text { Composite } \\
\text { face } \\
\text { sheet }\end{array}$ & $\begin{array}{l}\text { Adhesive } \\
\text { layer }\end{array}$ \\
\hline $\begin{array}{l}\text { Normal } \\
\text { modulus }\end{array}$ & Mpsi & $E$ & $\begin{array}{l}x x \\
y y \\
z z\end{array}$ & $\begin{array}{l}10.0 \\
10.0 \\
10.0\end{array}$ & $\begin{array}{l}19.4 \\
1.193 \\
1.193\end{array}$ & $\begin{array}{l}7.312 \\
7.312 \\
1.407\end{array}$ & $\begin{array}{r}0.3 \\
.3 \\
.3\end{array}$ \\
\hline $\begin{array}{l}\text { Shear } \\
\text { modulus }\end{array}$ & Mpsi & $G$ & $\begin{array}{l}x y \\
y z \\
z x\end{array}$ & $\begin{array}{l}3.85 \\
3.85 \\
3.85\end{array}$ & $\begin{array}{r}0.552 \\
.331 \\
.552\end{array}$ & $\begin{array}{r}2.783 \\
0.442 \\
.442\end{array}$ & $\begin{array}{l}.1034 \\
.1034 \\
.1034\end{array}$ \\
\hline $\begin{array}{l}\text { Poisson's } \\
\text { ratio }\end{array}$ & & v & $\begin{array}{l}x y \\
y z \\
z x\end{array}$ & $\begin{array}{r}0.312 \\
.312 \\
.312\end{array}$ & $\begin{array}{l}.26 \\
.424 \\
.26\end{array}$ & $\begin{array}{l}.3135 \\
.3135 \\
.275\end{array}$ & $\begin{array}{l}.45 \\
.45 \\
.45\end{array}$ \\
\hline $\begin{array}{l}\text { Thermal } \\
\text { expansion } \\
\text { coefficient }\end{array}$ & uin./in. $/^{\circ} \mathrm{F}$ & a. & $\begin{array}{l}x x \\
y y \\
z z\end{array}$ & $\begin{array}{l}12.6 \\
12.6 \\
12.6\end{array}$ & $\begin{array}{l}-.1732 \\
15.26 \\
15.26\end{array}$ & $\begin{array}{r}.9208 \\
.9208 \\
21.04\end{array}$ & $\begin{array}{l}57.02 \\
57.02 \\
57.02\end{array}$ \\
\hline $\begin{array}{l}\text { Thermal heat } \\
\text { conduct ivity }\end{array}$ & $\begin{array}{l}\text { Btu-in./hr } \\
\text { in. } 2 \%^{\circ} \mathrm{F}\end{array}$ & K & $\begin{array}{l}x x \\
y y \\
z z-\end{array}$ & $\begin{array}{l}6.166 \\
6.166 \\
6.166\end{array}$ & $\begin{array}{r}2.420 \\
.0297 \\
.0297\end{array}$ & $\begin{array}{c}1.225 \\
1.225 \\
.0297\end{array}$ & $\begin{array}{l}.0087 \\
.0087 \\
.0087\end{array}$ \\
\hline Density & $\mathrm{lb} / \mathrm{in} .^{3}$ & D & -- & .097 & .056 & .056 & .04 \\
\hline Heat capacity & Btu/lb & $C$ & -- & .22 & .1951 & .1951 & .25 \\
\hline
\end{tabular}

aThe $x-x$ direction is taken parallel to the fiber direction, $y-y$ perpendicular to it, and $z-z$ through the thickness.

TABLE II. - CORE EQUIVALENT MECHANICAL PROPERTIES

DETERMINED BY USING THREE-DIMENSIONAL DETAILED

FINITE ELEMENT MODEL

\begin{tabular}{|c|c|c|c|c|c|}
\hline \multirow[t]{2}{*}{ Property } & \multirow[t]{2}{*}{ Units } & \multirow[t]{2}{*}{ Symbol } & \multirow[t]{2}{*}{ Direct. } & \multicolumn{2}{|c|}{$\begin{array}{c}\text { Aluminum honeycomb } \\
\text { cell size }\end{array}$} \\
\hline & & & & $1 / 4 \mathrm{in}$. & $1 / 8 \mathrm{in}$. \\
\hline $\begin{array}{l}\text { Normal } \\
\text { modulus }\end{array}$ & $\begin{array}{l}\text { psi } \\
\text { psi } \\
\text { Mpsi }\end{array}$ & E & $\begin{array}{l}x x \\
y y \\
z z\end{array}$ & $\begin{array}{r}0.00178 \\
.00175 \\
.07541\end{array}$ & $\begin{array}{r}0.01423 \\
.01401 \\
.15083\end{array}$ \\
\hline $\begin{array}{l}\text { Shear } \\
\text { modulus }\end{array}$ & $\begin{array}{l}\text { Mpsi } \\
\text { psi }\end{array}$ & G & $\begin{array}{l}x y \\
y x\end{array}$ & $\begin{array}{l}.00797 \\
.00125\end{array}$ & $\begin{array}{l}.01560 \\
.01002\end{array}$ \\
\hline & Mpsi & & $\begin{array}{l}y z \\
z y\end{array}$ & $\begin{array}{l}.01065 \\
.01065\end{array}$ & $\begin{array}{l}.02147 \\
.02147\end{array}$ \\
\hline & Mpsi & & $\begin{array}{l}2 x \\
x z\end{array}$ & $\begin{array}{l}.01561 \\
.01775\end{array}$ & $\begin{array}{l}.03185 \\
.03572\end{array}$ \\
\hline $\begin{array}{l}\text { Poisson's } \\
\text { ratio }\end{array}$ & & v & $\begin{array}{l}x y \\
y x\end{array}$ & $\begin{array}{l}1.029 \\
1.024\end{array}$ & $\begin{array}{l}1.029 \\
1.024\end{array}$ \\
\hline & & & $\begin{array}{l}y z \\
z y\end{array}$ & 0.311741 & ${ }^{0} .311692$ \\
\hline & & & $\begin{array}{l}2 x \\
x z\end{array}$ & $0^{.311633}$ & $0^{.311680}$ \\
\hline Volume ratio & & & & .007467 & .014934 \\
\hline
\end{tabular}


TABLE III. - SUMMARY OF RESULTS FROM THREE DIFFERENT

SIMULATION LEVELS OF PROGRESSIVE SIMPLIFICATION

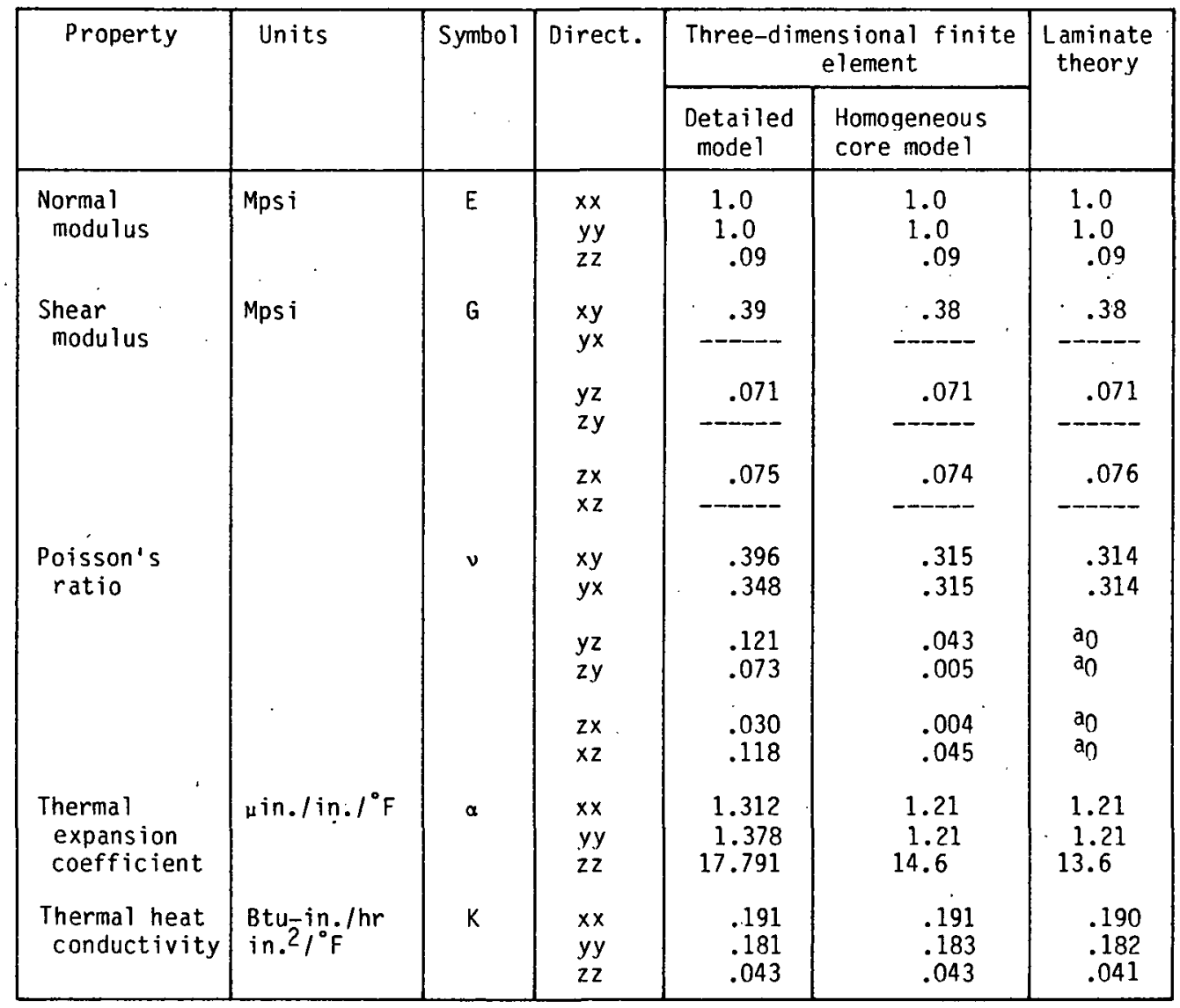

aWere set to "zero" in the laminate theory. 
TARLE IV. - SUMMARY OF EQUIVALENT CORE PROPERTIES OF $1 / 4$ IN. ALUMINUM HONEYCOMB

\begin{tabular}{|c|c|c|c|c|c|c|c|c|c|}
\hline \multirow[t]{3}{*}{ Property } & \multirow{3}{*}{ Units } & \multirow[t]{3}{*}{ Symbol } & \multicolumn{3}{|c|}{ Approximate equations } & \multicolumn{4}{|c|}{ Finite element analysis } \\
\hline & & & \multirow{2}{*}{$\begin{array}{l}\text { Faces } \\
\text { restrained }\end{array}$} & \multirow{2}{*}{$\begin{array}{l}\text { Faces } \\
\text { free }\end{array}$} & \multirow{2}{*}{$\begin{array}{l}\text { Faces } \\
\text { restrained }\end{array}$} & \multirow{2}{*}{$\begin{array}{l}\text { Faces } \\
\text { free }\end{array}$} & \multicolumn{2}{|c|}{ Single cell model } & \multirow{2}{*}{$\begin{array}{c}\text { Three-dimensional } \\
\text { detail model }\end{array}$} \\
\hline & & & & & & & $\begin{array}{c}\text { Faces } \\
\text { restrained }\end{array}$ & $\begin{array}{l}\text { Faces } \\
\text { free }\end{array}$ & \\
\hline Modulus & ksi & $\begin{array}{l}E_{\text {exx }} \\
E_{\text {eyy }} \\
E_{\text {ezz }} \\
G_{\text {exy }} \\
G_{\text {eyz }} \\
G_{\text {ezx }}\end{array}$ & $\begin{array}{l}1.0(t / w) E_{h \times x} \\
1.5(t / w) E_{h x x} \\
3(t / w) E_{h} \\
(3 / 4)(t / w) G_{h x y} \\
1.0(t / w) G_{h \times z} \\
1.5(t / w) G_{h z x}\end{array}$ & $\begin{array}{c}1.0\left(t^{3} / 4 w\right) E_{h x x} \\
1.5\left(t^{3} / 4 w\right) E_{h x x} \\
3.0(t / w) E_{h z z} \\
(t / w) G_{h x y} \\
1.0(t / w) G_{h z z} \\
1.0(t / w) G_{h z x}\end{array}$ & $\begin{array}{l}29.6 \\
44.4 \\
89.1 \\
22.3 \\
11.4 \\
17.1\end{array}$ & $\begin{array}{r}0.003 \\
.003 \\
89.1 \\
7.4 \\
11.4 \\
11.4\end{array}$ & $\begin{array}{l}28.5 \\
43.2 \\
69.7 \\
23.9 \\
10.5 \\
14.5\end{array}$ & $\begin{array}{c}0.002 \\
.002 \\
69.0 \\
6.9 \\
8.4 \\
8.0\end{array}$ & $\begin{array}{r}0.0 \\
.0 \\
75.4 \\
7.8 \\
10.6 \\
7.8\end{array}$ \\
\hline $\begin{array}{l}\text { Poisson's } \\
\text { ratio }\end{array}$ & & $\begin{array}{l}\text { vexz } \\
\text { veyz } \\
\text { vezx }\end{array}$ & $\begin{array}{l}v_{h x z} \\
v_{h z y} \\
v_{h z x}\end{array}$ & $\begin{array}{l}2 / \sqrt{3} \\
0 \\
v_{h z x}\end{array}$ & $\begin{array}{r}1.15 \\
.30 \\
.30\end{array}$ & $0^{.34} .30$ & $\begin{array}{l}.34 \\
.21 \\
.25\end{array}$ & $\begin{array}{l}1.0 \\
.00 \\
.30\end{array}$ & $\begin{array}{l}1.03 \\
.0 \\
.31\end{array}$ \\
\hline $\begin{array}{l}\text { Thermal } \\
\text { expansion } \\
\text { coefficient }\end{array}$ & $\mu$ in. $/$ in. $1^{\circ} \mathrm{F}$ & $\begin{array}{l}a_{e x x} \\
a_{e y y} \\
a_{e z z}\end{array}$ & $\begin{array}{l}a_{h x x} \\
a_{h x x} \\
a_{h z z}\end{array}$ & $\begin{array}{l}a_{h \times x} \\
a_{h \times x} \\
a_{h \geq 2}\end{array}$ & $\begin{array}{l}12.6 \\
12.6 \\
12.6\end{array}$ & $\begin{array}{l}12.6 \\
12.6 \\
12.6\end{array}$ & $\begin{array}{l}12.6 \\
12.6\end{array}$ & $\begin{array}{l}12.6 \\
12.6 \\
12.6\end{array}$ & $\begin{array}{l}12.6 \\
12.6 \\
12.6\end{array}$ \\
\hline $\begin{array}{l}\text { Thermal heat } \\
\text { conductivity }\end{array}$ & $\begin{array}{l}\text { Btu/in. } / \mathrm{hr} \\
\text { in. } 2, \% \mathrm{~F}\end{array}$ & $\begin{array}{l}{ }^{K} \text { exx } \\
K_{\text {eyy }} \\
K_{\text {ezz }}\end{array}$ & $\begin{array}{c}(4 / 3)(t / w) K_{h x x} \\
1.5(t / w) K_{h x x} \\
3(t / w) K_{h z z}\end{array}$ & $\begin{array}{c}(4 / 3)(t / w) K_{h x x} \\
1.5(t / w) K_{h x x} \\
3.0(t / w) K_{h z z}\end{array}$ & $\begin{array}{r}0.023 \\
.026 \\
.052\end{array}$ & $\begin{array}{l}.023 \\
.026 \\
.052\end{array}$ & --- & --- & $\begin{array}{l}.027 \\
.017 \\
.046\end{array}$ \\
\hline $\begin{array}{l}\text { Heat capac- } \\
\text { ity density }\end{array}$ & Btu/lb & $\mathrm{c}_{\mathrm{e}}$ & $3(t / w) C_{h}$ & $3.0(t / w) C_{k}$ & .002 & .002 & --- & --- & ------ \\
\hline Density & $\mathrm{lb} / \mathrm{in} .{ }^{3}$ & $\rho_{e}$ & $3(t / w)_{P h}$ & $3.0(t / w) o h$ & .00084 & .0008 & --- & ---- & .0007 \\
\hline
\end{tabular}



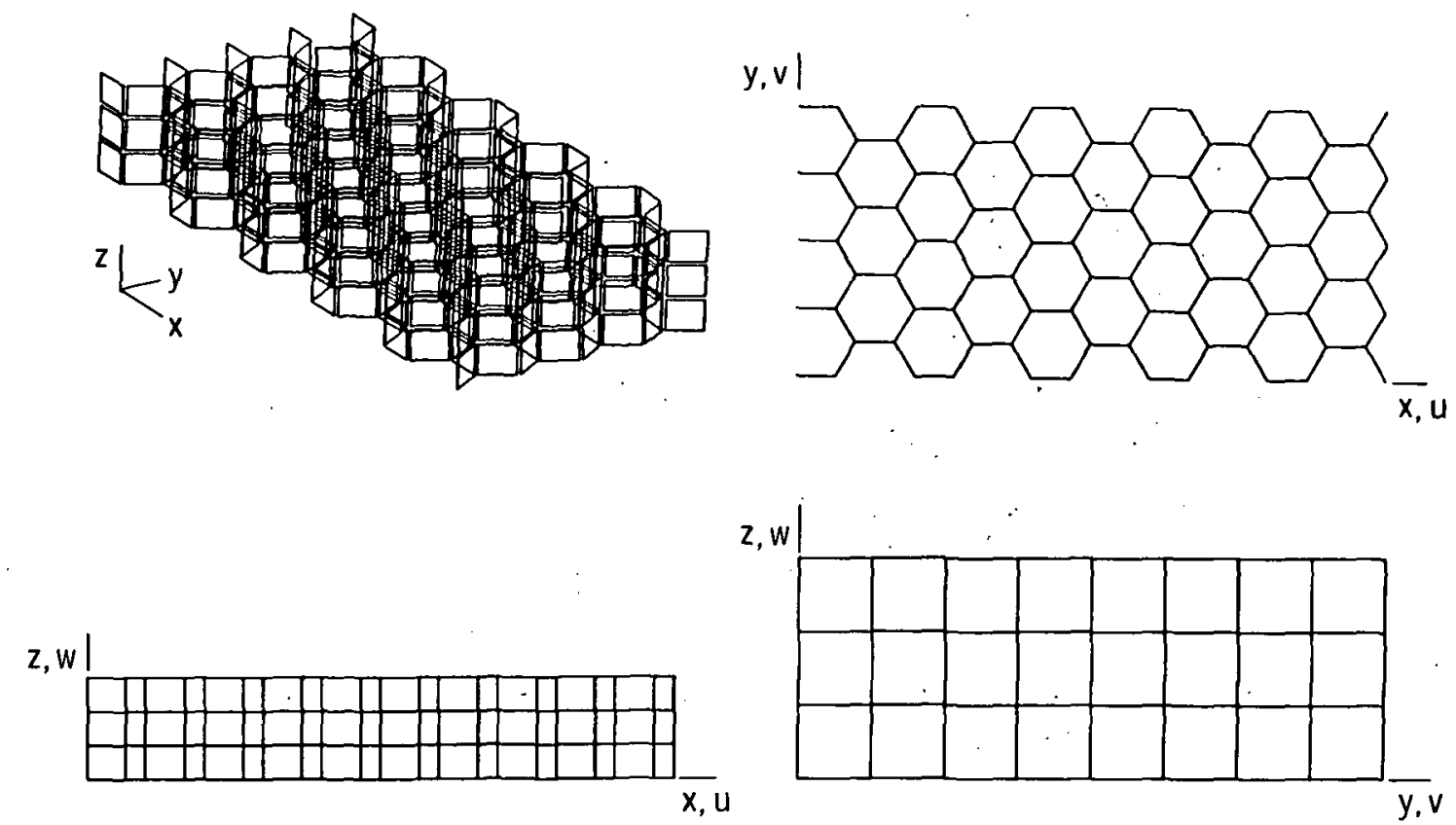

Figure 1. - Finite element model of aluminum honeycomb core (1/4-in. cell).

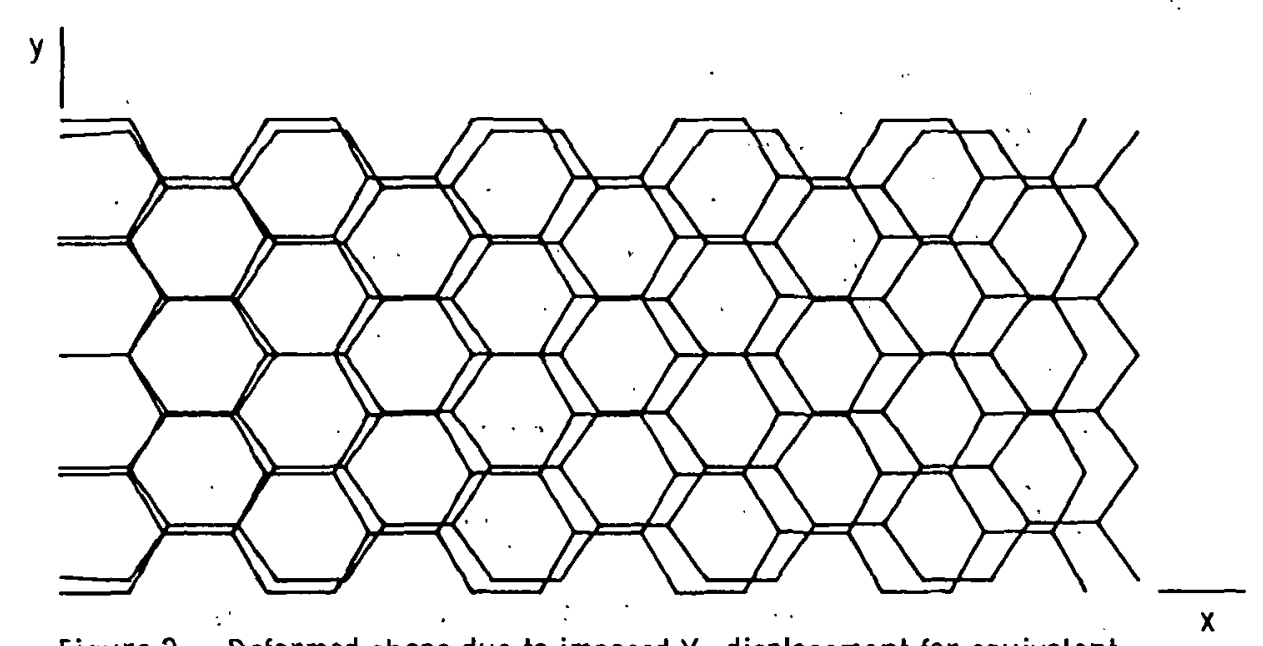

Figure 2. - Deformed shape due to imposed $X$ - displacement for equivalent $E_{\text {exx }}, v_{\text {exy }}$, and $v_{\text {exz }}$. (Overall model dimensions: $x=2.165 ; y=1.0$; $z=0.375 ; 1 / 4$-in. cells.) 


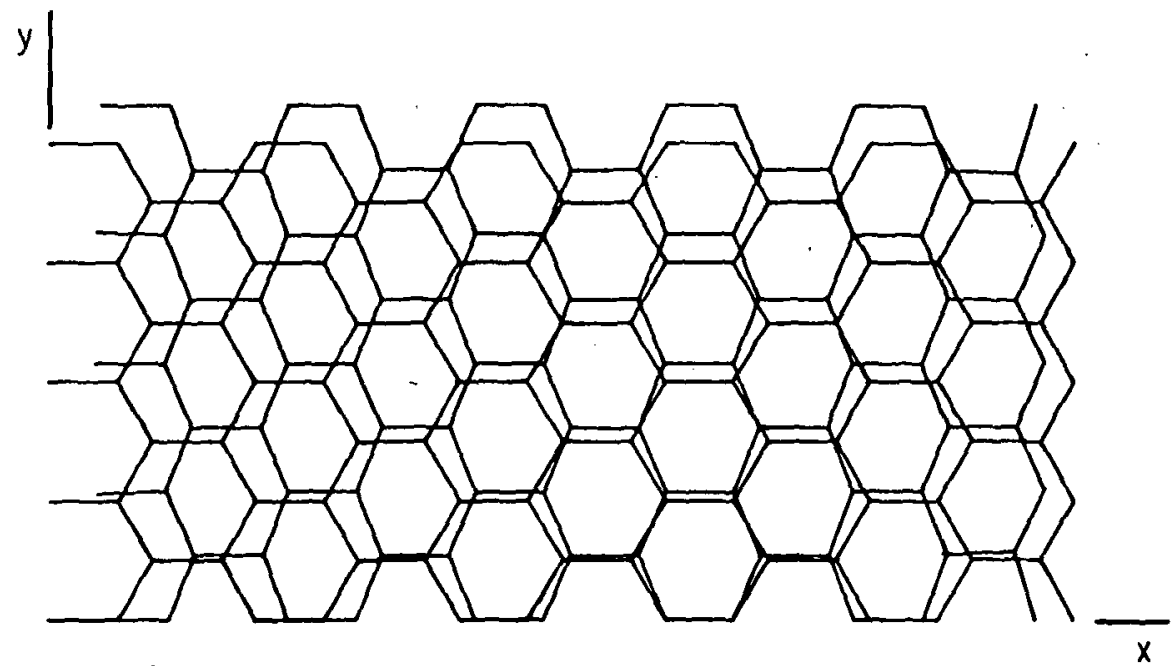

Figure 3. - Deformed shape due to imposed $Y$-displacement for equivalent $E_{\text {eyy, }}, v_{\text {eyx }}$, and $v_{\text {eyz. }}$.

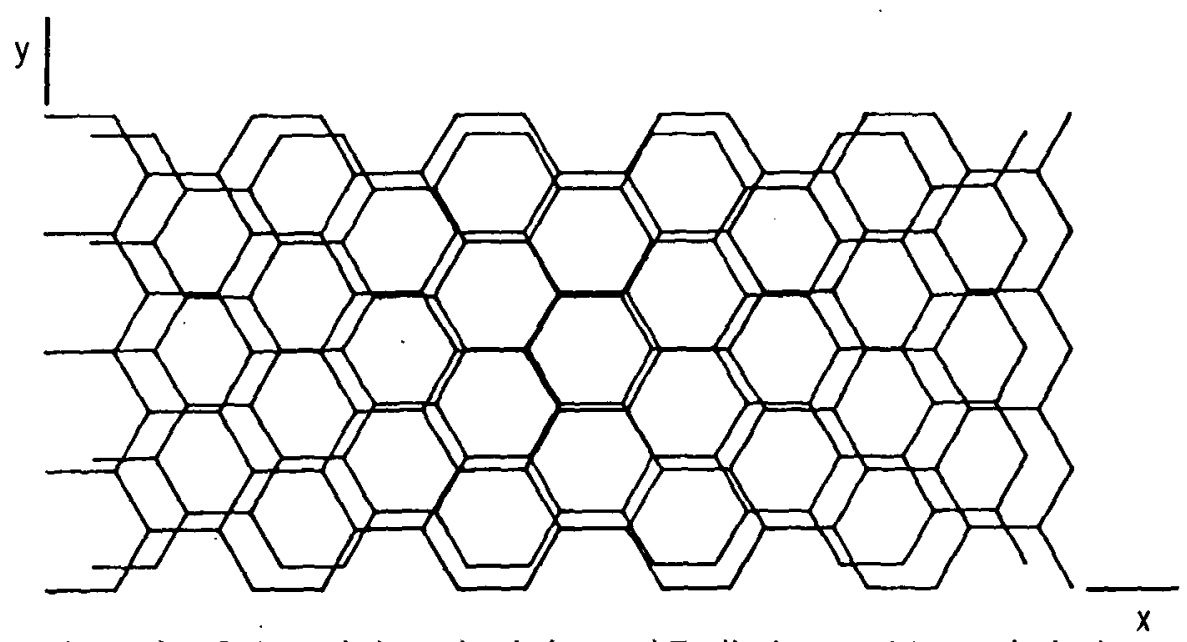

Figure 4. - Deformed shape due to imposed Z- displacement for equivalent $E_{e z z}, v_{e z x}$, and $v_{e z y}$. 

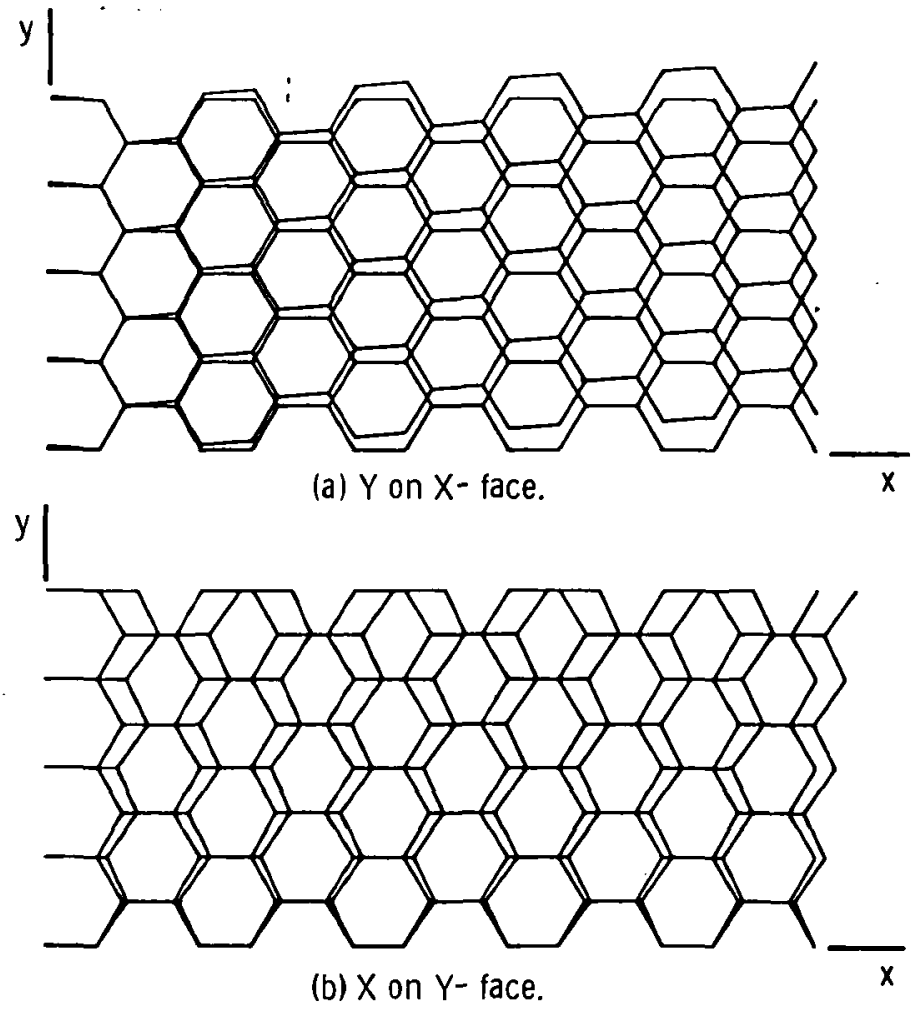

Figure 5. - Deformed shape due to imposed displacement for equivalent $G_{\text {exy }}$ and $G_{\text {eyx }}$.

$\circ$

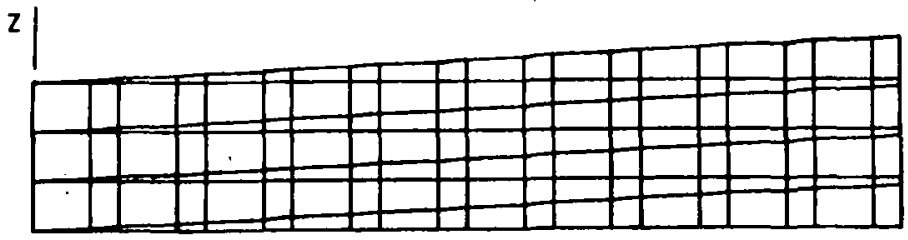

(a) Z on X-face.

z|

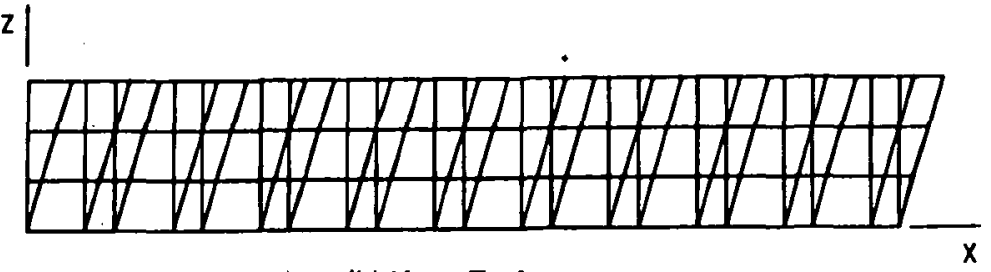

(b) $X$ on Z- face.

Figure 6. - Deformed shape due to imposed displacement for equivalent $G_{\text {exz }}$ and $G_{\text {ezx }}$. 


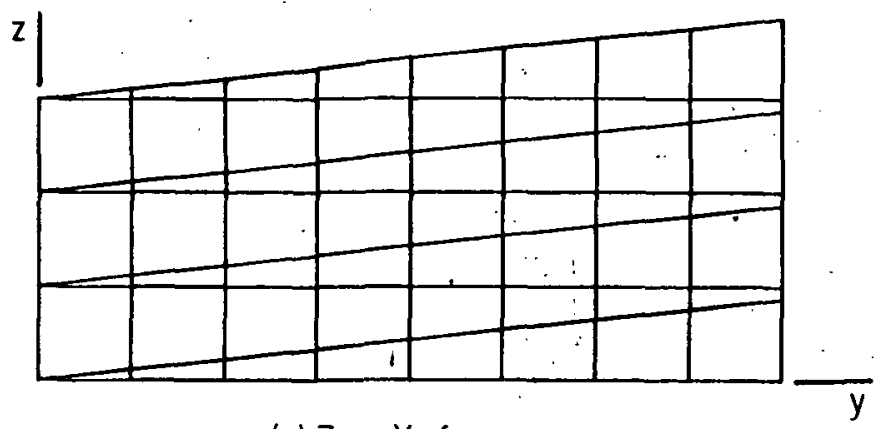

(a) Z on $Y$ - face.

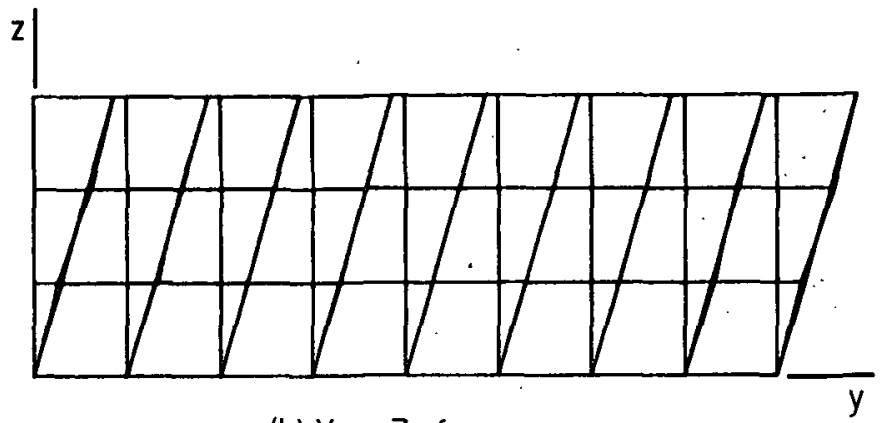

(b) $Y$ on Z- face.

Figure 7. - Deformed shape due to imposed displacement for equivalent $G_{\text {eyz }}$ and $G_{\text {ezy. }}$.

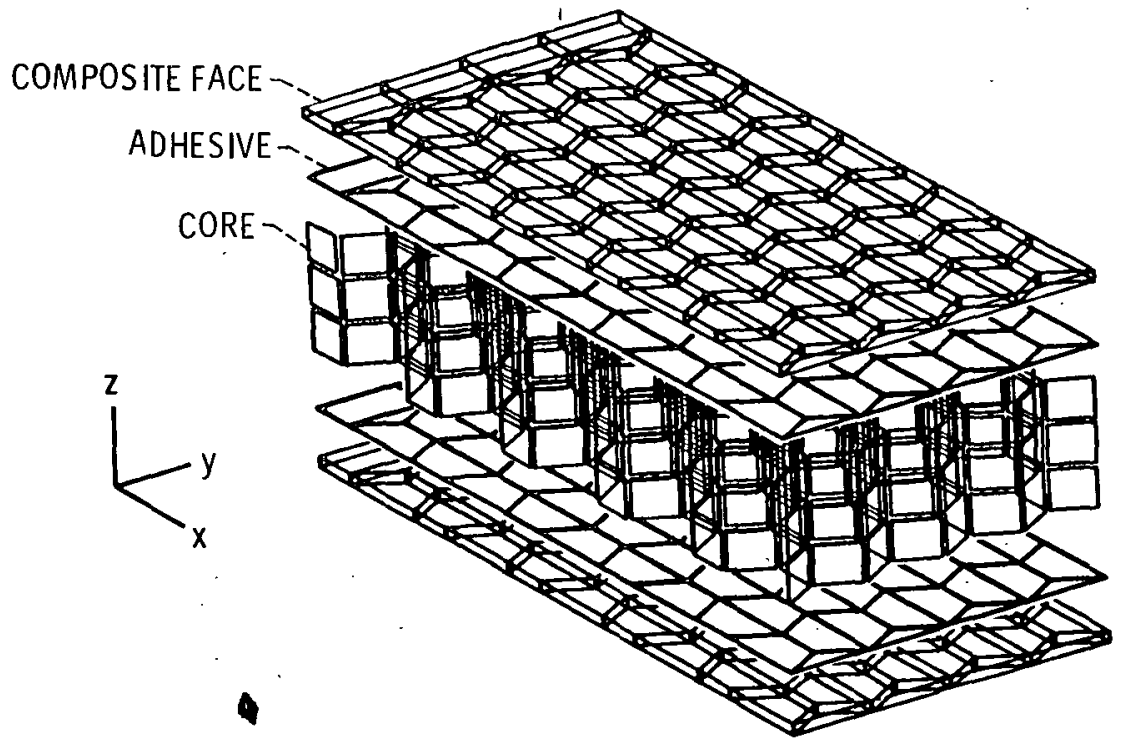

Figure 8. - 3-D detailed fiñite element model of composite sandwich with honeycomb core. (All sandwich components are modeled with solid finite elements except honeycomb core.) 


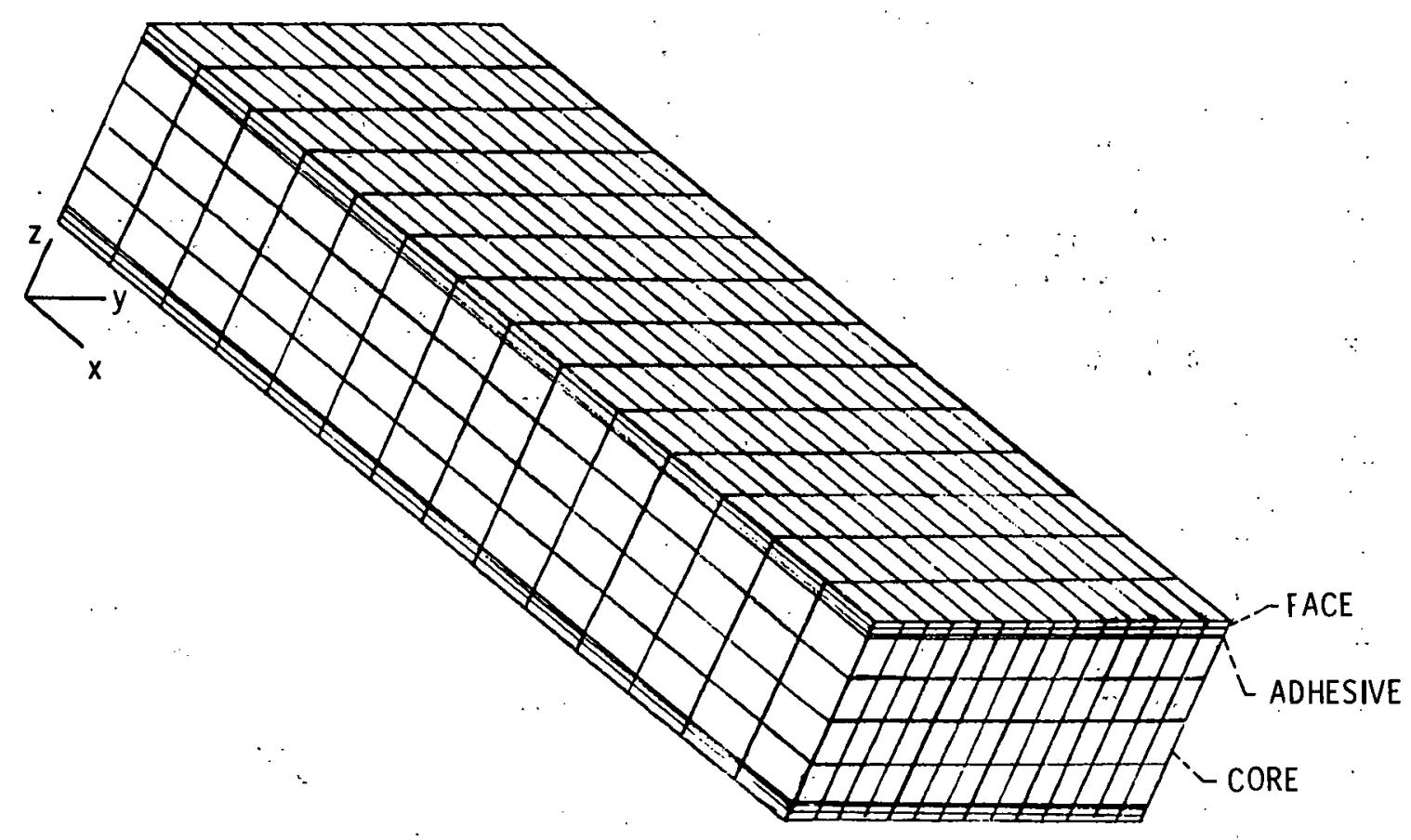

Figure 9. - 3-D finite element model of composite sandwich with equivalent homogeneous core. 
ICAN COORDINATE SYSTEM
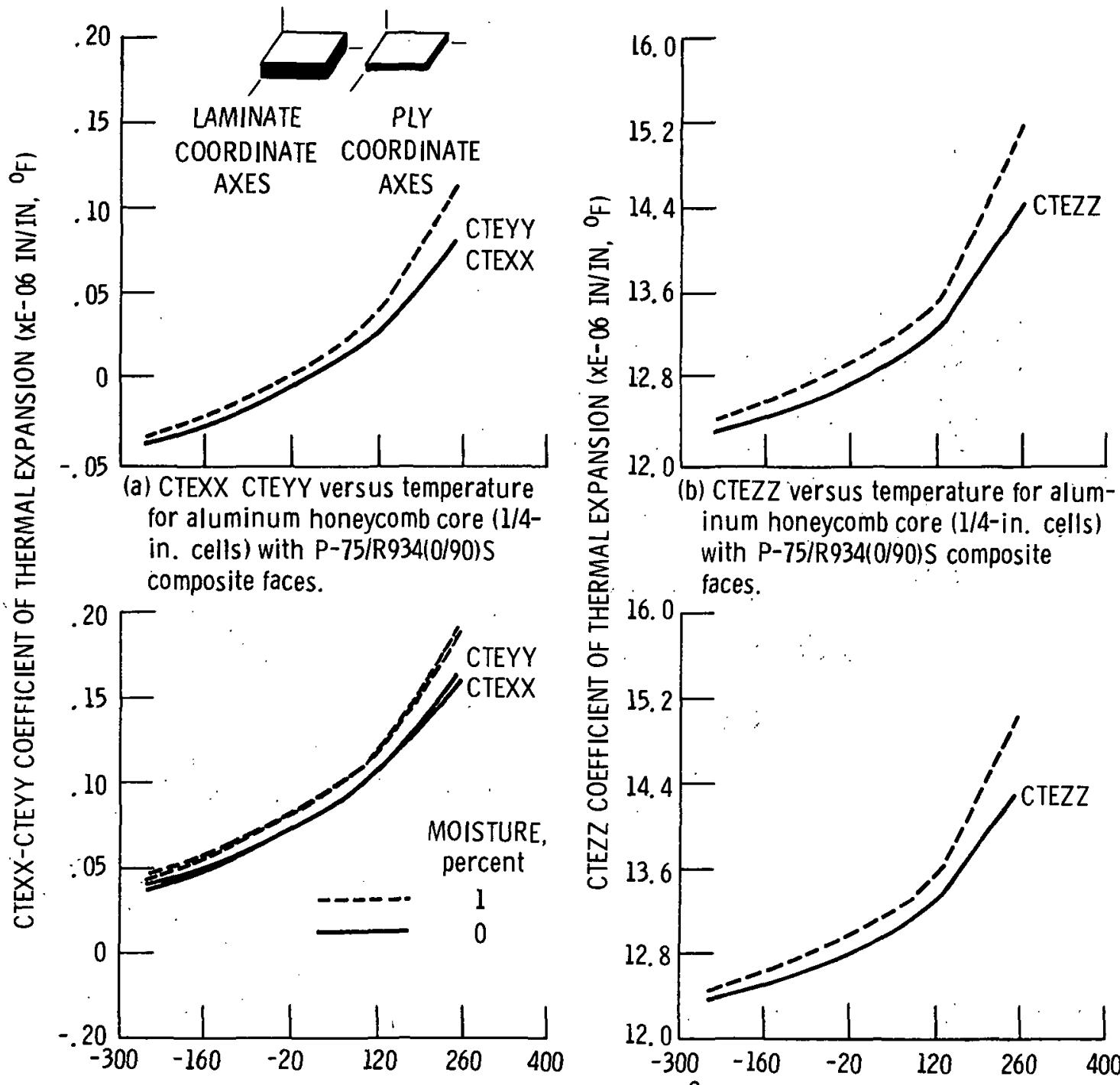

齐

(b) CTEZZ versus temperature for aluminum honeycomb core (1/4-in. cells) with P-75/R934(0/90)S composite faces.

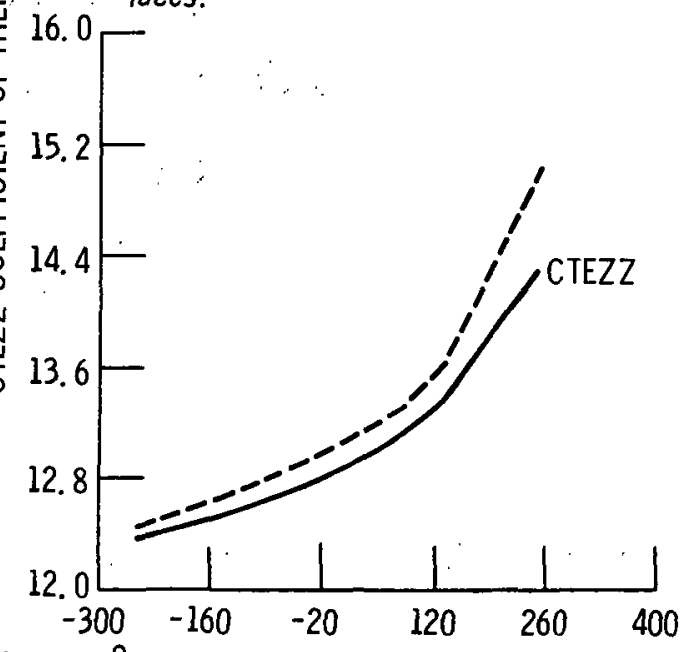

(c) CTEXX-CTEYY versus temperature for aluminum honeycomb core [1/4in. cells) with $P-75 / R 934(0 / \pm 00) S$ composite faces.

(d) CTEZZ versus temperature for aluminum honeycomb core (1/4-in. cells) with P-75/R934(0/ \pm 60$) S$ composite faces.

Figure 10. - Thermal expansion coefficients of composite sandwich panels with graphite fiber/epoxy faces and aluminum honeycomb core. 


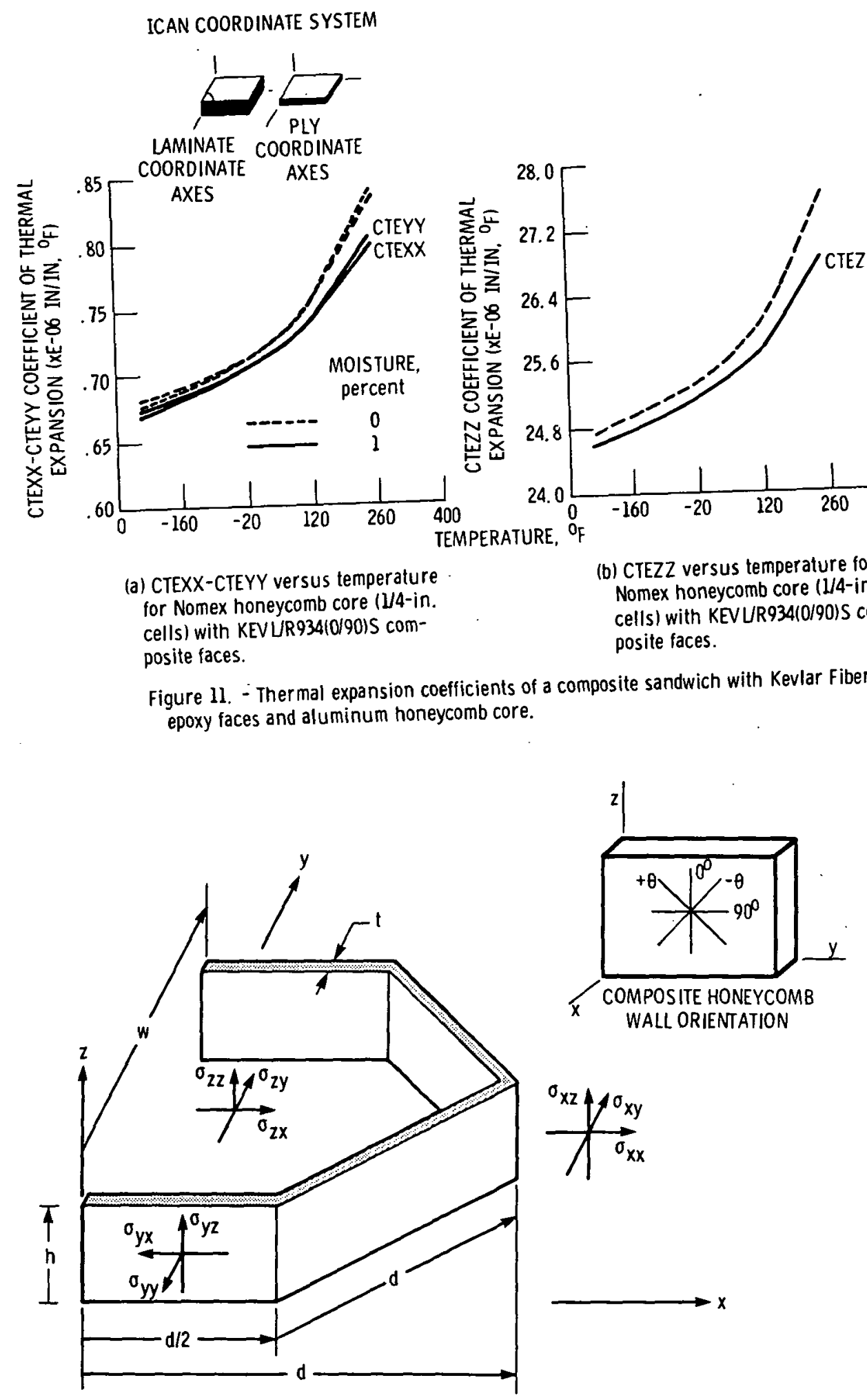

Figure 12. - Schematic for deriving approximate equations for equivalent honeycomb properties. 


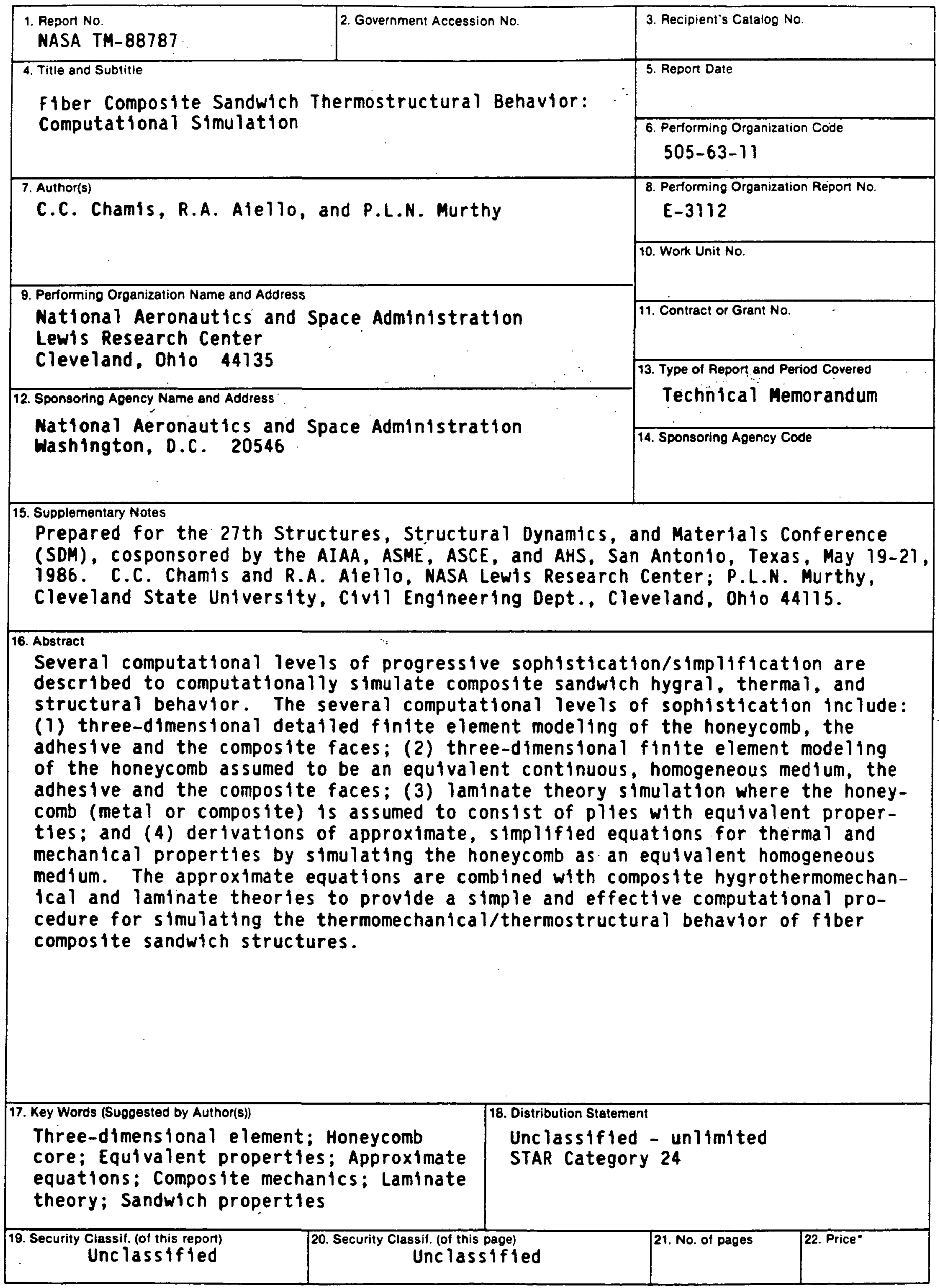

"For sale by the National Technical Information Service, Springfield, Virginia 22161 